\title{
KAJIAN FENOMENOLOGI TENTANG PERAN AYAH DALAM MERAWAT ANAK DENGAN AUTIS
}

\author{
Devi Amelia1, Yufitriana Amir², Darwin Karim \\ ${ }^{1}$ PSIK Universitas Riau, ${ }^{2}$ PSIK Universitas Riau, ${ }^{3}$ PSIK Universitas Riau \\ Program Studi Ilmu Keperawatan Universitas Riau Jalan Pattimura No 9 Gedung G Pekanbaru Riau \\ Kode Pos 28131 Indonesia \\ Email: Ameliadevi70@yahoo.com
}

\begin{abstract}
Abstrak
Anak autis adalah anak dengan kebutuhan khusus yang memiliki sindrom seperti penyimpangan perkembangan sosial, kemampuan berbahasa, dan perilaku adaptif dalam lingkungan. Peran orang tua sangat dibutuhkan dalam pengasuhan anak-anak. Peran yang dilengkapi dengan bekerja sama dalam bertanggung jawab yang seimbang dapat mempengaruhi tumbuh dan kembang anak yang baik. Penelitian ini bertujuan untuk mengidentifikasi peran ayah dalam merawat anak dengan autis dengan desain penelitian kualitatif dan pendekatan fenomenologi di salah satu pusat autis di Pekanbaru. Data didapatkan melalui wawancara mendalam (in depth interview) yang dianalisis menggunakan metode Colaizzi. Tiga partisipan yang mempunyai anak autis berpartisipasi berdasarkan kriteria inklusi. Hasil penelitian didapatkan tiga tema utama yaitu keterlibatan dalam pengasuhan anak, dukungan yang diberikan ayah, dan terapi yang dilakukan ayah. Hasil penelitian ini menunjukkan bahwa dalam perawatan anak autis ayah dan ibu membagi perannya dalam merawat anak dengan cara seimbang karna tidak hanya ibu saja yang terlibat dalam perawatan anak melainkan ayah juga terlibat dalam perawatan anak autis. Peran ayah dan ibu sama-sama bertanggung jawab dalam perkembangan anak. Penelitian ini menyarankan agar peran ayah, dapat ditingkatkan dalam merawat anak autis dalam melakukan terapi.
\end{abstract}

Kata kunci: anak autis, keterlibatan, perkembangan, pendidikan, peran ayah

\begin{abstract}
Autism is children with special need. They have problem in social development, using language, and adaption with the environment. The parents' role is really needed in caring of the autis children. The role which is completed with working together between their father and mother and make a balance in caring responsibility. This harmonious efforts influence the children growth. This aim of this research was to identify the father's role in caring of the autism children using qualitative and phenomenology approach. Data was collected by in depth interview and analyzed using Colaizzi method. Three participants were participated. Three themes were identified: active participation in caring, supporting system by their father, and active involvement on autism therapy. The result of this research showed that both mother and father divided their role to take care of them equally. The roles of both mother and father was important to get care children's with autis and their growth.
\end{abstract}

Keywords: Children, autism, participation, education, growth, father role 
Devi Amelia ${ }^{1}$, Yufitriana Amir ${ }^{2}$, Darwin Karim $^{3}$,Kajian Fenomenologi Tentang Peran Ayah Dalam Merawat Anak Dengan Autis

\section{PENDAHULUAN}

Anak autis adalah anak dengan kebutuhan khusus. Autisme merupakan sindrom (kumpulan gejala) yang terjadi penyimpangan perkembangan sosial, kemampuan berbahasa, dan perilaku adaptif dalam lingkungan (Elvira \& Hadisukanto, 2010). Anak autis adalah anak yang berbeda dengan anak-anak pada umumnya, yaitu memerlukan kebutuhan khusus dalam aktivitas sehari-harinya yang disebut dengan Gangguan Spektrum Autistik (GSA). Autis bukan suatu penyakit namun suatu cacat perkembangan seumur hidup yang mempengaruhi bagaimana orang melihat, mendengar, merasakan dunia dan ketidakmampuan berinteraksi dengan orang lain. (Elvira \& Hadisukanto, 2010).

Elvira dan Hadisukanto menyatakan autis adalah gangguan dalam interaksi sosial, sedikit melakukan komunikasi non-verbal dan pola perilaku yang terbatas dan berulang stereotipik, ditemukan pada usia 3 tahun. Gangguan ini dijumpai 3-4 kali lebih banyak pada anak laki-laki dibanding dengan anak perempuan. Anak autisme memiliki gangguan karakteristik perilaku dalam interaksi sosial dengan teman sebaya dan mengalami kegagalan dalam membuat persahabatan, keterlambatan komunikasi dan bahasa bahkan menggunakan suatu kata satu kali dan tidak akan menggunakannya lagi selama seminggu, sebulan, atau beberapa tahun, dan anak autisme memiliki perilaku stereoptipik, ketidakstabilan mood dan afek, serta respons terhadap stimuli sensorik yang berlebihan ataupun kurang terhadap responsif stimuli sensorik yang diberikan (Kaplan dkk, 2010).

Jumlah penderita autis terus bertambah setiap tahunnya, baik di negara maju maupun di negara berkembang. Prevalensi (angka kejadian) anak autisme meningkat secara dramatis selama dekade terakhir. Salah satunya negara maju, di Amerika dalam National Autism Center menyatakan penelitian Centers of Disease Control (CDC) pada tahun 2014 angka kejadian autis terdapat 1 dari 42 anak laki-laki dan 1 dari 189 anak perempuan. Prevalensi autis di Indonesia juga mengalami peningkatan. Jumlah pasti penyandang autis di Indonesia belum diketahui, namun diperkirakan pada tahun 2015 terdapat 134.000 penyandang spektrum autis (Judarwanto, 2015). Biasanya autisme lebih sering ditemukan pada anak laki-laki dibanding anak perempuan, 2,6-4 : 1, karena anak laki-laki mudah mendapat gangguan fungsi otak. Namun anak perempuan penyandang autis mempunyai gejala yang lebih berat pada test inteligensi mempunyai hasil rendah dibanding anak laki-laki (Elvira \& Hadisukanto, 2010).

Jumlah penyandang autisme di Provinsi Riau juga belum diketahui dengan pasti. Berdasarkan data dari dinas pendidikan provinsi Riau. Pendataan yang dilakukan pendidikan khusus dan pendidikan layanan khusus (PK-PLK) pada tahun 2016 anak penyandang autis di Riau yang terdaftar di 
pemerintah berjumlah 340 orang. Jumlah anak autis di Pekanbaru yang terdaftar di sekolah luar biasa (SLB) Pekanbaru sebanyak 150 orang.

Gangguan yang dimiliki anak autisme bervariasi dari satu anak ke anak lainnya. Seseorang dapat dinilai apabila mengalami kesulitan terus-menerus dengan komunikasi dan interaksi sosial, pola berulang dalam berperilaku. Diagnosis adalah identifikasi formal autisme yang dilakukan oleh tim diagnostik multi-disipliner yang terdiri dari ahli syaraf, psikolog anak-anak, ahli perkembangan anak-anak, dan terapis bahasa (Muhith, 2015). Manfaatnya untuk mendapatkan penilaian yang tepat waktu dan menyeluruh serta membantu orang autis (keluarga mereka, mitra, pengusaha, rekan, guru dan teman-teman) untuk memahami mengapa pada anak autisme mengalami kesulitan tertentu dan apa yang bisa mereka lakukan untuk mengakses layanan dan dukungan dengan terdiagnosis autis. Disamping ditangani tenaga kesehatan peran orang tua sangat mempengaruhi terhadap kesembuhan anak (Asmika, 2006).

Orang tua dengan anak penyandang autis memiliki tingkat stress yang berlebihan dikarenakan belum siap menghadapi permasalahan terhadap anak (Farida, 2015). Orangtua memiliki peranan penting dalam mensosialisasikan anak, dikarenakan setiap aktivitas anak mulai dari bangun tidur hingga anak tidur malam orang tua sangat berperan dalam perkembangannya. Perkembangan anak autis mengalami keterlambatan dari anak lain seusianya. Oleh sebab itu orang tua perlu memahami tanda dan gejala dari autis. Penanganan yang dilakukan dengan cepat, besar pula peluang anak untuk mengurangi gejala terhadap anak. Orang tua yang memiliki anak yang berkebutuhan khusus mengalami suka duka tersendiri dalam merawatnya, hal ini tergantung pada berat ringannya gangguan yang dialami anak (Noor, 2014).

Beberapa penelitian mengenai pengasuhan anak menyoroti peranan ibu terhadap anak. Ibu umumnya lebih dapat menerima keberadaan anak apa adanya, karena ibu lebih banyak berperan dalam proses perkembangan anak. Kelekatan antara anak dan ibu sudah terjalin sejak anak berada didalam kandungan dan proses menyusui (Martin, 2010). Peranan ayah biasanya lebih berorientasi pada pekerjaan, sementara tugas untuk mengurus anak baik pengasuhan maupun pendidikan diserahkan pada ibu (Friedman, 2010). Secara emosional, ayah kurang berperan dalam pengasuhan anak bila dibandingkan ibu sehingga penerimaan ayah dalam menerima kenyataan mengenai anak autis jauh lebih sulit (Friedman, 2010).

Penelitian kualitatif tentang pengalaman ibu dalam merawat anak berkebutuhan khusus autis di Banjarbaru dilakukan oleh Marlinda (2011). Partisipan yang terdiri dari 9 orang ibu yang memiliki anak autis. Penelitian ini ditemukan bahwa ibu yang memiliki anak autis 
Devi Amelia ${ }^{1}$, Yufitriana Amir ${ }^{2}$, Darwin Karim ${ }^{3}$, Kajian Fenomenologi Tentang Peran Ayah Dalam Merawat Anak Dengan Autis

membutuhkan perawatan khusus, merasa berbeda dengan orangtua lainnya, mencari usaha pengobatan, menyikapi reaksi lingkungan, perasaan ibu serta kebutuhan dan harapan terhadap anaknya. Penelitian tersebut menjelaskan bahwa peranan ibu terhadap anak autisme sangat mempengaruhi kebutuhan seorang anak dan lingkungannya.

Ayah berperan sebagai kepala rumah tangga, selain mencukupi kebutuhan keluarganya, mendisiplinkan anak-anak dan membangun kecerdasan emosional anak. Friedman (2010) menyatakan peranan ayah digambarkan sebagai pengawas moral dalam kepemimpinan keluarga, pencari nafkah dan model peran jenis kelamin terutama terhadap anak laki-laki. Ayah berperan penting dalam setiap perkembangan sosial anak (Wijanarko \& Setiawati, 2016). Keterlibatan ayah secara positif, anak akan lebih percaya diri dalam berhubungan dengan orang lain. Ayah memiliki gaya interaksi unik yang memberikan kontribusi penting bagi perkembangan bahasa dan simbolis pada perkembangan anak (Flippin \& Crais, 2011).

Anak dengan diagnosis autisme mememerlukan kebutuhan khusus dalam berperilaku, berkomunikasi dan membutuhkan arahan serta pengawasan dalam berhubungan dengan orang lain. Ayah sebagai motivator bagi anak yang berkebutuhan khusus. Pada anak autisme mengalami kesulitan dalam perilaku dan berinteraksi, ayah dapat memberikan dorongan seperti motivasi.
Motivasi yang diberikan ayah akan sangat mempengaruhi mental anak sehingga dapat membuatnya menjadi lebih percaya diri dalam menghadapi kesulitannya.

Dampak ayah terhadap perkembangan anak autisme adalah dapat mengatasi stress dan frustasi, mempunyai ketrampilan, memecahkan masalah dan dapat beradaptasi (Wijanarko \& Setiawati, 2016). Anak yang memiliki ayah terlibat dalam pengasuhan dirinya, memiliki tingkat kepuasan hidup yang tinggi dan mempunyai distress psikologis yang rendah. Anak akan lebih tahan dengan berbagai stimulus stress yang ada, dan mengetahui solusi terhadap berbagai permasalah yang muncul dalam hidupnya. Oleh sebab itu, anak yang berkebutuhan khusus memerlukan pendidikan, model atau contoh bersikap, berpikir, bertindak, dari seorang ayah (Martin, 2010).

Berdasarkan penelitian tentang pengalaman ibu dalam merawat anak autis usia sekolah di Pekanbaru dilakukan oleh Noor (2014) ibu memiliki peranan penting dalam merawat anak autis usia sekolah, yang terlihat dari pengalaman ibu sejak anak terdiagnosis autis hingga mengatasi masalah dalam perawatan anak autis tersebut. Seorang anak yang berkebutuhan khusus tidak lepas dari pengasuhan ibunya dalam arti mendidik dan menjaganya. Ibu lebih berperan terhadap pengurus rumah tangga dan pengasuhan anak, sehingga yang mengetahui perkembangan anak adalah ibu (Friedman, 2010). 
Berdasarkan hasil studi pendahuluan dengan wawancara terhadap tiga dari empat orang ayah yang memiliki anak autisme, didapat bahwa adanya ayah yang tidak memiliki banyak waktu bersama anaknya, ada yang sibuk mencari nafkah, dan ada yang merasa bukan perannya dalam pengasuhan anak. Hal seperti ini ayah merasa bahwa dalam melakukan pengasuhan anak berkebutuhan khusus diberi tanggung jawab kepada ibu sedangkan ayah hanya mencari nafkah bagi keluarganya. Berdasarkan fenomena tersebut maka peneliti tertarik untuk melakukan penelitian yang berjudul " Peran ayah dalam merawat anak dengan autis".

Hasil penelitian ini diharapkan dapat mengetauhi sejauh mana peranan ayah dalam merawat anak autis dan juga sebagai data dasar meningkatkan peran serta khususnya ayah dalam merawat anak autis.

\section{METODE PENELITIAN}

Penelitian ini dilaksanakan di Pusat Layanan Autis Provinsi Riau Pekanbaru yang dimulai dari bulan Februari sampai bulan Agustus 2017. Penelitian ini merupakan sebuah penelitian kualitatif dengan pendekatan fenomenologi. Polit dan Beck (2010) mengatakan bahwa penelitian kualitatif cenderung menggunakan aspek pengalaman manusia yang dinamik dengan pendekatan yang holistic untuk menguraikan pengalaman tersebut. Penelitian kualitatif dilihat berdasarkan sudut pandang dan realitas yang tidak dipahami atau diketahui sebelumnya (Polit dan Beck, 2010).

Populasi penelitian ini adalah seluruh ayah yang memiliki anak penyandang autis di Pusat Layanan Autis Pekanbaru sebanyak 73 orang. Jumlah partisipan dalam penelitian ini yaitu sebanyak 3 orang partisipan. Desain penelitian yang dilakukan yaitu fenomenologi.

Partisipan yang terlibat adalah ayah yang memiliki anak autis yang sedang menjalani terapi di Pusat Layanan Autis. Kepala pusat layanan autis menanyakan kesediaan ayah sebagai responden. Poses wawancara dilakukan dengan satu per satu untuk menjaga privasi responden. Pengolahan dan transkrip data dilakukan dengan metodel Colaizi.

\section{HASIL PENELITIAN}

Semua partisipan dalam penelitian adalah ayah memiliki anak autis yang ada di Pusat Layanan Autis. Jumlah anak autis adalah tujuh belas orang, satu orang tidak mempunyai ayah dan yang bersedia menjadi partisipan penelitian ini berjumlah tujuh orang. Yang terdiri dari empat orang studi pendahuluan dan tiga orang yang dipilih dengan metode purposive sampling dan ditentukan berdasarkan prinsip saturasi data. Distribusi frekuensi berdasarkan karakteristik responden dijelaskan pada tabel di bawah ini.

Tabel 1.

Karakteristik partisipan

Karakteristik Partisipan


Devi Amelia ${ }^{1}$, Yufitriana Amir ${ }^{2}$, Darwin Karim $^{3}$,Kajian Fenomenologi Tentang Peran Ayah Dalam Merawat Anak Dengan Autis

\begin{tabular}{lccc}
\hline & 1 & 2 & 3 \\
\hline Usia & 38 tahun & $\begin{array}{c}40 \\
\text { tahun }\end{array}$ & 42 tahun \\
\hline Jenis Kelamin & Laki-laki & $\begin{array}{c}\text { Laki- } \\
\text { laki }\end{array}$ & Laki-laki \\
\hline Suku & Melayu & Minang & Batak \\
\hline Pendidikan & S1 & S1 & SMA \\
\hline $\begin{array}{l}\text { Pekerjaan } \\
\text { Agen } \\
\text { travel }\end{array}$ & $\begin{array}{c}\text { Pedaga } \\
\text { ng }\end{array}$ & Tidak bekerja \\
\hline $\begin{array}{l}\text { Lama anak } \\
\text { menjalani } \\
\text { terapi }\end{array}$ & 1 bulan & 1 tahun & 2 tahun \\
\hline
\end{tabular}

Partisipan berperan secara langsung memberikan perananya dalam bentuk pendidikan, seperti mengajar ngaji, huruf dan membaca.

"Apalagi saya guru mesjid si adik dirumah diajar juga dalam huruf dan membaca... Ya sangat berperan, soalnya kalau hanya perempuan yang ini dia tidak sejalan" (P1)

Partisipan berperan secara langsung

Hasil analisa terhadap verbatim dari ketiga partisipan tersebut mendapatkan 3 tema utama yakni, Keterlibatan dalam pengasuhan anak, dukungan yang diberikan ayah, dan terapi yang dilakukan ayah. Tema-tema yang dihasilkan dari penelitian ini dibahas secara terpisah untuk mengungkap makna atau arti dari berbagai peranan partisipan. Tema-tema tersebut saling berhubungan satu sama lainnya untuk menjelaskan suatu esensi dari peranan ayah dalam merawat anak dengan autis.

\section{Keterlibatan dalam Pengasuhan anak}

Tema ini muncul dari peran partisipan dalam keterlibatan pengasuhan anak. Peranan dari masing-masing partisipan berbeda, ada yang secara langsung dan ada yang secara tidak langsung.

Secara Langsung

Partisipan yang melakukan secara langsung memberikan peranannya dalam ikut serta untuk memberikan yang terbaik untuk merawat anaknya. Hal ini dapat dilihat dari jawaban yang diberikan partisipan, berikut ungkapannya: memberikan perawatan fisik terhadap anak dengan membersihkan anak, memberi makan dan memandikannya.

"sore kita (saya) bersihkan, pokoknya beres udah cuci semua udah dimandiin udah makan, kalau makan pun saya ajak untuk makan sendiri jadi kita tidak dimarahin sama ibuknya sepulang kerja"(P3).

Secara tidak langsung

Partisipan yang melakukan secara tidak langsung, yang berperan dalam merawat anaknya adalah istri partisipan yang melakukan apabila berada didalam rumah. Istri yang membantu anak mengerjakan pekerjaan rumah dari terapi. Hal ini dapat dilihat dari jawaban yang diberikan partisipan, berikut ungkapannya:

"Jadi peran saya sebetulnya tetap berdua saya dengan istri. Istri bagian internal dirumah saya bagian eksternal. Apa maksudnya internal, setiap pulang dari sini kan anak saya tu kan ada pr dikasih tugas-tugas dari ee terapis disini untuk dipraktekkan dirumah." (P2).

\section{Dukungan yang diberikan ayah}

Tema ini muncul dari suatu dukungan yang dilakukan partisipan terhadap anak autis. 
Dukungan dari masing-masing partisipan secara umum dapat dikategorikan menjadi dua yaitu, instrumental dan emosional.

Dukungan instrumental

Partisipan yang memberikan dukungan instrumental ingin membuat anak partisipan betah berada di rumah. Hal ini dapat dilihat dari jawaban yang diberikan partisipan, berikut ungkapannya:

"Materi subhanallah, apapun keinginan anak misalnya ya... pokoknya dalam fasilitas kebutuhan anak.. contohnya kebutuhan yang yang materi lah ac, vcd semua lengkap, bagaimana kasur empuk sebagaimana rupa anak itu betah. Jadi dirumah itu diberi seperti surga" (P1).

a. Dukungan emosional

Partisipan juga memberikan dukungan emosional yaitu menunjukkan kepedulian terhadap terapi anak. Hal ini dapat dilihat dari jawaban yang diberikan partisipan, berikut ungkapannya:

"Saya ingin dia mendapatkan pendidikan seperti terapi, dan setiap hari saya nyari informasi tempat lain yang ada juga yang gratis gitu yaa.. dan di PLA inilah saya yang ngantarin bolak-balik untuk terapi" (P3).

\section{Peran ayah dalam memberikan terapi}

Tema ini muncul dari terapi yang dilakukan partisipan terhadap anak autis. Terapi yang dilakukan dari masing-masing partisipan berbeda, ada terapi perilaku, okupasi, wicara dan sosialisasi.

Terapi perilaku

Partisipan yang melakukan terapi perilaku dengan memberikan dorongan yang positif untuk menjalankan aktivitas yang lebih banyak. Seperti anak dapat memperhatikan dengan duduk tenang dalam waktu lebih dari satu jam atau melakukan kontak mata lebih dari lima detik apabila diberi instruksi. Hal ini dapat dilihat dari jawaban yang diberikan partisipan, berikut ungkapannya:

Partisipan mengungkapkan bahwa dengan melakukan bersama dengan istri maka akan mendapatkan hasil yang maksimal dalam melakukan terapi perilaku.

"Mau.. kalau disuruh duduk ya dia mau, kalau kita panggil berbicara dia bisa memperhatikan, yah walaupun tidak lama ya. Ya Alhamdulillah itu aja karna itu semua kunci dari rumah tangga, ha.. kalau suami istri itu harus balance.. karna harus harmonis subhanallah" (P1)

Partisipan mengungkapkan banyaknya perubahan setelah melakukan terapi di PLA.

"Sangat banyak perkembangan yang dulunya tidak bisa tatap mata, sekarang sudah bisa tatap mata" (P2).

Partisipan mengungkapkan bahwa anaknya mau melakukan apa yang diperintah apabila diberitahu pada saat itu juga

"Saya selalu ngasih tau dia kalau ada sesuatu yang dia lakuin itu gak benar. Misalnya ya, "M... baik-baik duduknya, gak boleh begitu gak boleh begini" yah dia bisa lakukan saat dikasih tau, cuman yaa hanya saat itu saja, tapi kontaknya itu kuranglah" (P3).

Terapi okupasi

Partisipan yang melakukan terapi okupasi mencoba membantu agar dapat melakukannya sendiri. Terapi okupasi yang diajarkan dirumah untuk anak autis yaitu 
Devi Amelia ${ }^{1}$, Yufitriana Amir ${ }^{2}$, Darwin Karim $^{3}$,Kajian Fenomenologi Tentang Peran Ayah Dalam Merawat Anak Dengan Autis

memegang pensil dan sendok. Hal ini dapat dilihat dari jawaban yang diberikan partisipan, berikut ungkapannya:

"Cuman nulis lah.. karna dirumah biasanya dipegangin diginiin ya haa" (P1)

"Terapi okupasi saya udah ajarin kalau sedang makan bersama untuk megang sendok sendiri, tapi yang namanya anak susah makan yah terpaksa istri saya yang nyuapin"(P2)

a. Terapi wicara

Partisipan tidak melakukan terapi wicara mengajarkan kepada anak dari tugas yang diberikan dari terapis. Dapat dilihat dari ngomong perkataannya.

\section{b. Terapi sosialisasi}

Partisipan melakukan terapi sosial mengajarkan kepada anak agar dapat mengetahui lingkungan sekitarnya. Hal ini dapat dilihat dari jawaban yang diberikan partisipan, berikut ungkapannya:

"Bawa dia main-main, dia kan harus dibawa ke kolam berenang, ya saya ajak dia ke lapangan main bola" (P2)

\section{PEMBAHASAN}

Penelitian tentang peran ayah dalam merawat anak dengan autis telah mengidentifikasi tiga tema yaitu: keterlibatan dalam pengasuhan anak, dukungan yang diberikan ayah dan terapi yang dilakukan ayah. Keterlibatan ayah dalam pengasuhan

Hasil penelitian menunjukkan bahwa keterlibatan ayah dalam memberikan pengasuhan anak berbeda-beda, dapat dikategorikan menjadi dua yaitu secara langsung dan secara tidak langsung. Menurut Lamb (2010) keterlibatan ayah mencakup tindakan yang berada dalam pengawasan yang luas terhadap anak. Hal ini dilihat dari aspek pemantauan ayah, tercermin dalam mengetahui keberadaan anak, partisipasi ayah dalam pengambilan keputusan.

$$
\text { Partisipan yang menunjukkan }
$$

pengasuhan secara langsung memberikan peranan dalam bentuk pendidikan dan perawatan fisik. Peranan pendidikan diberikan partisipan melalui mengajar ngaji, huruf dan membaca. Partisipan juga melakukan perawatan fisik terhadap anak dengan membersihkan anak, memberi makan dan memandikannya. Lamb (2010) mengemukakan bahwa keterlibatan sebagai kontak langsung ayah dengan anaknya, melalui pemeliharaan dan aktivitas bersama dengan memberikan perhatian waktu dan interaksi langsung dengan anaknya. Jenis kegiatan interaktif ini berpotensi mendorong perkembangan anak.

Hasil penelitian ini didukung oleh penelitian Potter (2017) yang berjudul "Father involvement in the care, play, and education of children with autism" yang menyebutkan ayah menghabiskan waktu dalam bermain bersama anaknya daripada aktivitas lainnya, walaupun hampir setengahnya tidak mendapatkan pelatihan yang relevan. Banyaknya ayah yang mendukung pendidikan anak-anak mereka, terutama membantu pekerjaan rumah.

Sedangkan partisipan yang secara tidak langsung dalam melakukan pengasuhan anak 
mengatakan bahwa yang berperan dalam pengasuhan anaknya adalah istri partisipan yang melakukan apabila berada didalam rumah. Karena istri yang membantu anak mengerjakan pekerjaan rumah dari terapi. Partisipan juga mengatakan telah membagibagi peran bersama istrinya untuk merawat anak dengan berkebutuhan khusus. Memberikan pengasuhan terhadap anak autis dengan melakukan bersama akan memberikan hasil perkembangan yang positif. Allen \& Daly (2007) mengemukakan efek dari hubungan sesama orangtua yang mendukung, memberikan peranan bagi para ayah dan akan memiliki hasil perkembangan anak yang positif.

Penyebab munculnya keterlibatan pengasuhan secara tidak langsung seseorang dapat muncul karena didalam berumah tangga telah membagi perannya untuk merawat anak dengan autis, adanya peranan yang mengajarkan anak dalam melakukan pekerjaan dirumah yang diberi terapis adalah ibu, dan ayah melakukan aktivitas yang berhubungan bermain bersama anaknya. Partisipan mengatakan anak merupakan titipan Allah yang harus dijaga, tidak hanya ibu saja yang melakukan pengasuhan anak, melainkan ayah juga ikut berperan agar memberikan keseimbangan dalam pengasuhan seorang anak.

1. Dukungan yang diberikan ayah

Hasil penelitian menunjukkan bahwa dukungan dari masing-masing partisipan secara umum dapat dikategorikan menjadi dua yaitu, instrumental dan emosional. Menurut Friedman (2010) dukungan instrumental merupakan sumber pertolongan praktis dan konkrit diantaranya, bantuan langsung dari orang yang diandalkan seperti materi, tenaga, pelayanan. Manfaat dari dukungan ini adalah individu merasa diperhatikan atau diperdulikan dari lingkungannya. Penyebab dukungan instrumental timbul dari partisipan yang menunjukkan ingin memberikan perhatian terhadap anak dalam bentuk materi dan anak tidak akan merasa kekurangan dalam fasilitas. Partisipan mengungkapkan bahwa adanya ac, vcd, kasur empuk agar anak itu betah sehingga anak dapat merasakan dirumah itu seperti surga. Dukungan instrumental yang diberikan berupa materi dapat membentuk karakter anak yang diberikan ayah.

Hasil penelitian ini didukung oleh penelitian Kerns (2015) mengatakan dukungan dasar yang aman merupakan aspek kunci keterikatan ayah dengan anak. Hubungan ibuanak dan ayah-anak berhubungan dengan penyesuaian dan penanganan sekolah anakanak.

Friedman (2010) mengatakan dukungan emosional (kepedulian) merupakan dukungan dalam bentuk perhatian secara emosional yang diterima seseorang dari orang lain berupa kehangatan, empati, kepedulian dan perhatian sehingga merasa diperhatikan. Dukungan ini sangat penting dalam menghadapi keadaan yang dianggap tidak dapat dikontrol. Penyebab 
Devi Amelia ${ }^{1}$, Yufitriana Amir ${ }^{2}$, Darwin Karim $^{3}$,Kajian Fenomenologi Tentang Peran Ayah Dalam Merawat Anak Dengan Autis

dukungan emosional timbul dari kepedulian partisipan yang memberikan pendidikan terhadap anaknya, dengan mencari tempat terapi. Motivasi serta dorongan dari partisipan menunjukkan adanya perkembangan dari anak, mulai dari anak tidak bisa tatap mata hingga bisa tatap mata, anak tidak bisa mengatakan apa-apa hingga sekarang bisa menyebutkan beberapa kata.

Hasil penelitian ini didukung oleh penelitian Harmaini (2014) yang menyebutkan dukungan afeksi (memberikan perhatian) dan dukungan pengasuhan lebih dominan dalam cara ayah merawat anaknya. Hal ini mengisyaratkan, keberhasilan seorang anak dimasa depan lebih ditentukan oleh kekuatan dukungan afeksi dan dukungan pengasuhan ayah. Dukungan afeksi dan pengasuhan dari sudut padang ayah lebih pada perawatan psikologis, pembentukan karakter anak.

2. Terapi yang dilakukan ayah

Tema ini muncul dari terapi yang dilakukan partisipan terhadap anak autis. Terapi yang dilakukan dari masing-masing partisipan berbeda, dikategorikan dalam bentuk terapi perilaku, okupasi, wicara dan sosialisasi. Menurut Veague (2010) mengemukakan terapi perilaku merupakan pengobatan yang paling penting yang dilakukan untuk anak autis, dengan menghilangkan perilaku yang tidak diinginkan atau berbahaya untuk meningkatkan perilaku positif yang bermanfaat bagi orang lain.
Ayah menunjukkan bahwa dalam mengajarkan anak melakukan terapi dirumah adalah ibu (internal) yaitu tiba anak dirumah ibu membantu anak dalam mengajarkan juga melakukan tugas atau pekerjaan rumah dari terapis. Sedangkan partisipan melakukan peran dalam terapi bagian eksternal, yaitu dalam mengantar anak bolak-balik ke tempat terapi, mengajak anak bersosialisasi diluar rumah.

Hasil penelitian ini didukung oleh penelitian Oktavia (2014) yang menyatakan terdapat pengaruh positif penggunaan terapi perilaku dengan metode Applied Behavior Analysis terhadap kemandirian anak autis. Kemandirian anak meningkat sesudah penerapan terapi perilaku dengan metode applied behavior analysis. Kemandirian anak meningkat mulai dari anak datang disekolah sampai anak siap menerima pembelajaran dikelas.

Proses perawatan untuk anak autis tidak hanya dilakukan oleh ibu saja melainkan ayah juga terlibat dalam perawatan anak autis dimana dalam pembagian peran. Peran ayah dan ibu sama-sama bertanggung jawab dalam perkembangan anak. Hasil penelitian ini juga didukung oleh penelitian Merianto (2016) yang menyebutkan terdapat hubungan yang signifikan antara penyesuaian diri orang tua dan peran mereka dalam terapi anak autism. Sehingga perhatian terhadap orang tua dengan anak autism sangatlah penting, karena dengan penerimaan dan penyesuaian diri yang baik 
diharapkan peran aktif mereka semakin baik dalam berbagai upaya penanganan autism untuk menunjang keberhasilan terapi.

\section{SIMPULAN}

Berdasarkan data yang didapat dari 3 orang partisipan yang merupakan ayah dengan anak yang sedang menjalani terapi di PLA maka hasil penelitian ini dibagi 3 tema yaitu: Keterlibatan dalam pengasuhan anak, dukungan yang diberikan ayah, dan terapi yang dilakukan ayah. Peran masing-masing partisipan dalam merawat anak dengan autis berbeda-beda. Partisipan telah membagi perannya dalam merawat anak autis bersama ibu. Partisipan yang melakukan pengasuhan anak secara langsung memberikan peranan dalam bentuk pendidikan dan perawatan fisik, sebaliknya partisipan yang malakukan pengasuhan anak secara tidak langsung dimana ibu yang berperan dalam melakukan mengajarkan anak berada didalam rumah dengan membantu anak mengajarkan tugastugas dari terapi dan mengajarkannya saat anak dirumah.

Dukungan instrumental yang diberikan partisipan menunjukkan ingin memberikan perhatian terhadap anak dalam bentuk materi dan agar anak tidak merasa kekurangan dalam fasilitas sedangkan dukungan emosional yang diberikan partisipan dalam bentuk kepedulian partisipan yang memberikan pendidikan terhadap anaknya dalam bentuk terapi, dengan mencari tempat terapi untuk memfasilitasi keadaanya. Terapi perilaku, wicara dan okupasi terhadap anak autis dirumah dilakukan oleh ibu, dimana ibu dominan dalam mengajarkan terapi tersebut daripada partisipan. Akan tetapi dalam terapi sosialisai partisipan berperan aktif dalam mengajak anak beraktivitas dan bermain keluar rumah dengan tujuan anak dapat beradaptasi dan mengetahui lingkungan sekitarnya. Ayah dan ibu telah membagi perannya dalam merawat anak dengan cara seimbang karna tidak hanya ibu saja yang terlibat dalam perawatan anak melainkan ayah juga terlibat dalam perawatan anak autis. Peran ayah dan ibu sama-sama bertanggung jawab dalam perkembangan anak.

\section{SARAN}

Bagi masyarakat

Hasil penelitian ini diharapkan dapat jadi evidence based dalam peranan ayah dalam merawat anak autis dan juga sebagai data dasar meningkatkan peran serta khususnya ayah dalam merawat anak autis dalam melakukan terapi.

\section{Bagi perkembangan ilmu keperawatan}

Hasil penelitian ini diharapkan dapat memberikan informasi, bahan literatur, dan wawasan baru dalam ilmu pediatrik sehingga dapat meningkatkan pelayanan keperawatan berkualitas dalam hal pendekatan psikoterapi dengan cakupan proses keperawatan.

\section{Bagi peneliti selanjutnya}

Peneliti selanjutnya disarankan lebih menggali secara mendalam dampak peranan 
Devi Amelia ${ }^{1}$, Yufitriana Amir ${ }^{2}$, Darwin Karim $^{3}$,Kajian Fenomenologi Tentang Peran Ayah Dalam Merawat Anak Dengan Autis

ayah dalam melakukan terapi terhadap anak autis.

\section{DAFTAR PUSTAKA}

Asmika. (2006). Hubungan motivasi orangtua untuk mencapai kesembuhan anak dengan tingkat pengetahuan tentang penanganan anak penyandang autisme dan spektrumnya. Malang: Fakultas Kedokteran Universitas Brawijaya. Skripsi. Diperoleh tanggal 29 Mei 2017 dari

http://jkb.ub.ac.id/index.php/jkb/article/vie wFile/230/222

Elvira, S. D., \& Hadisukanto, G. (2010). Buku ajar psikiatri. Jakarta: Universitas Indonesia.

Farida. (2015). Bimbingan keluarga dalam membantu anak autis. Jawa tengah: STAIN Kudus.

Flippin, M., \& Crais, E. (2011). The need for more effective father involvement in early autism intervention. Chapell hill: University Of North Carolina. Jurnal. Diperoleh tanggal 29 Mei 2017 dari http:// journals.sagepub.com/doi/abs/10.1177/105 3815111400415

Friedman, M.M. (2010). Buku ajar keperawatan keluarga: riset, teori, \& praktik. Edisi 5. Jakarta: EGC.

Harmaini. (2014). Peran ayah dalam mendidik anak. Skripsi. Tidak dipubliskan. Pekanbaru: UIN.

Judarwanto, W. (2015). Jumlah penderita autis di Indonesia. Diperoleh tanggal 22 Februari 2017 dari https://klinikautis.com

Kaplan, H. I, Sadock, B. J., \& Grebb, J. A. (2010). Sinopsis psikiatri. Edisi 2. Jakarta: Bina Rupa Aksara.

Kerns. (2015). Assessing both safe haven and secure base support in parent-child relationships. Journal of the society for emotion and attachment studies.

Lamb, M. (2010). The role of the father in child development. $5^{\text {th }}$ Ed. New Jersey: Jhon Wiley \& Sons, Inc.

Marlinda, E. (2011). Pengalaman ibu dalam merawat anak dengan kebutuhan khusus: autis di Banjabaru Kalimantan Selatan.
Depok: Fakultas Ilmu Keperawatan Program Magister Keperawatan.

Martin, L. (2010). Financial planning for autis child. Yogyakarta: Ar-Ruzz Media.

May Institute. (2009). ABA. Diperoleh Pada Tanggal 22 Januari 2017. Dari Https://Www.Mayinstitute.Org

Merianto. (2016). Peran orang tua dalam menangani anak autis (studi kasus 4 keluarga anak autis di kota pekanbaru). Pekanbaru: Jurusan Sosiologi Fakultas Ilmu Sosial dan Ilmu Politik UR.

Muhith, A. (2015). Pendidikan Keperawatan Jiwa Teori Dan Aplikasi. Yogyakarta :Pustaka Nasional.

Oktovia. (2014). Efek terapi perilaku dengan metode applied behavior analysis terhadap kemandirian anak autis. Program studi PGSD: Universitas sebelas maret.

Polit, D. F., \& Beck, C. T. (2010). Appraising evidence for nursing practice. Edisi 7. Philadelphia: Lippicot Williams \& Wilkins.

Vuague, H. B. (2010). Autism. New York: Infobase Publishing.

Wijarnako, J., \& Setiawati, E. (2016). Parenting digital. Jakarta: Bumi Bintaro Permai.

Noor, M. (2013). Pengalaman ibu dalam merawat anak dengan autis usia sekolah. Skripsi. PSIK: Universitas Riau. 